\title{
ANTÍGONA DE SÓFOCLES E A QUESTÃO JURÍDICA FUNDAMENTAL: A ETERNA TENSÃO ENTRE SEGURANÇA JURÍDICA E CORREÇÃO
}

\author{
EDUARDO SEINO WIVIURKA ${ }^{1}$
}

ReSumo: A Antígona de Sófocles possui um lugar de destaque na Filosofia do Direito. Essa tragédia expressa dilemas jurídicos e oferece símbolos que comportam múltiplas interpretações. Através dos séculos a obra foi lida, majoritariamente, a partir de um viés dualista em que pretensões de justiça antagônicas de Antígona e Creonte se chocam - a satisfação de um ponto de vista implica a destruição do outro. Entretanto, François Ost ofereceu uma nova interpretação à tensão proposta por Sófocles, encontrando um terceiro momento em que a conciliação entre os opostos é possível. Tal momento seria ocupado pela função jurisdicional em que o hermeneuta buscaria a melhor conciliação entre as partes litigantes. Esta pesquisa, após discutir um panorama geral de Antígona e detalhar a contribuição de Ost, vai além de Ost e argumenta a partir de nomes de destaque na Filosofia do Direito contemporânea (a saber, Habermas, Alexy e Dworkin) como que a tensão presente em Antígona é análoga estruturalmente a questões jurídicas enfrentadas ao longo da história.

Palavras-chave: justiça; tragédia; filosofia do direito; desobediência civil; François Ost.

\begin{abstract}
"Antígona, que é, em todos os sentidos, uma das obras mais sublimes e mais perfeitas de todos os tempos." (Hegel)

"Não é lícito aos mortais evitar as desgraças que o destino lhes reserva." (Sófocles)
\end{abstract}

\footnotetext{
Professor de Filosofia e de Direito Constitucional no Curso de Direito do Centro Universitário Curitiba (UNICURITIBA). Doutorando em Filosofia pela Universidade Federal do Paraná (UFPR). Mestre em Direito pela Universidade Federal do Paraná (UFPR). Especialista em Formação Pedagógica do Professor Universitário pela Pontifícia Universidade Católica do Paraná (PUCPR). Bacharel em Direito pelo Centro Universitário Curitiba (UNICURITIBA). Curitiba (PR), Brasil. CV Lattes: http://lattes.cnpq.br/2763403841685669. ORCID: https://orcid.org/oooo-0003-38133522. E-mail: seinoew@gmail.com.
} 


\section{INTRODUÇÃO}

Antígona tem a mesma importância para o Direito que Édipo Rei tem para a Psicanálise. Édipo matou seu pai e casou-se com sua mãe, situação que levou Sigmund Freud a teorizar o complexo de Édipo - que expressa os desejos hostis que meninos sentem pelos pais e os impulsos amorosos em relação às mães. Em Édipo Rei foi retratado o dilema que serviu como pedra fundamental para a Psicanálise Freudiana.

Por seu turno, Antígona traz outro conflito chave - não mais entre a pessoa e sua família, mas sim entre a família e a sociedade. Na última parte da trilogia tebana é retratado o dilema fundamental do Direito, que permanece essencialmente o mesmo desde a Grécia Antiga até os dias de hoje.

Como é próprio do gênero tragédia, há a expressão de contradições irreconciliáveis, levando a inevitável angústia gerada pela impossibilidade de solucionar a tensão sem implicar em alguma perda. São utilizados signos para expressar o conflito, os quais podem receber intepretações diferentes a partir da tentativa da narrativa de mediar dois extremos.

Das leituras jurídicas, a tragédia sofocliana apresenta um conflito entre Direito e Justiça. Em termos mais complexos, pode-se falar que há uma tensão entre segurança jurídica, função típica do Direito posto, e a necessidade de correção, no sentido que o conteúdo do Direito seja conforme ou aceitável aos valores de determinada época. Esse conflito foi interpretado ao longo dos séculos de diferentes maneiras e por uma pluralidade de autores, porém não é o propósito deste estudo discutir a infinidade de vieses literários, jurídicos e filosóficos, mas sim expor uma interpretação recente que busca dar um passo além das dualidades.

Esta pesquisa objetiva aprofundar uma discussão sobre Antígona iniciada por François Ost. O jurista belga entende que mesmo que a tragédia de Sófocles exponha extremos inconciliáveis, há a possibilidade de mediação entre os lados em julgamentos que acontecem na narrativa. A Filosofia do Direito, ao discutir a justiça, e a Teoria do Direito, ao desenvolver modelos teóricos explicativos, não podem se limitar a identificar elementos conflitantes. Direito e Justiça colidem há séculos, e desde sempre teóricos buscaram a melhor mediação entre essas ordens diferentes. O ponto culminante dessa tensão, e próprio da tarefa do jurista, 
é harmonizar da melhor forma possível o que o Direito posto manda e o que os valores reclamam no momento de uma decisão jurídica. A harmonização excelente consiste em uma eterna busca do hermeneuta.

Para promover a discussão proposta, esta pesquisa divide-se em três partes. Em um primeiro momento será apresentada a tragédia grega que é objeto de reflexões, na qual, de forma breve, o enredo central da narrativa será apresentado, bem como mostraremos a importância de Antígona na história da literatura. Ficará claro porque performances da peça Antígona são realizadas em todo mundo até os dias de hoje e não raro, nos cursos de Direito, são feitos julgamentos simulados sobre a violação à lei positiva que a protagonista cometeu.

Na segunda parte, serão discutidas leituras da obra, especialmente as feitas por juristas. A maioria delas são leituras dualistas e cada nome mencionado poderia render um estudo próprio, mas o objetivo da exposição será apresentar o referencial que servirá como contraste para a interpretação de Ost, que oferece uma contribuição em que os pontos de vistas opostos fazem contato. Ele, então, parte para um terceiro momento que vai além das contradições antes vistas como insuperáveis.

Por fim, indo além de Ost, será discutido como que Antígona expressa o dilema fundamental da função de jurista, que pode ser localizado na obra de Sófocles. Trata-se do conflito entre segurança jurídica e correção que será colocado a partir de mediações com o pensamento de Jürgen Habermas e Robert Alexy. Ambos os juristas reconhecem uma tensão inevitável do fenômeno jurídico que aparece no momento da concretização do Direito por meio da atuação de um magistrado.

Estudos como esse propõe uma interdisciplinaridade entre Direito e Literatura, nas quais existem várias interseções possíveis entre os campos. Pode-se discutir o Direito na literatura, Direito da literatura, ou a literatura enquanto exercício crítico para avaliar direitos. De todas as formas, a literatura ajuda a fundamentar e interpretar a realidade, por vezes até a antecipar questões jurídicas. Em última instância, a arte escrita é fonte de experiência de vida, e nisso concede metáforas úteis ao Direito.

De forma mais elevada, trata-se do diálogo entre a arte e a realidade. O Direito diz como a realidade deve ser; a arte mostra como a realidade poderia ser. Ambos têm seu mundo simbólico que por vezes se encontram, 
e, quando isso acontece, a literatura inspira-nos a olhar o mundo de outra forma, à luz do belo e de elevadas metáforas. Depois de contemplar tal expressão elevada, nunca mais olhamos para a realidade simplesmente como ela é ou deveria ser.

Dentro da discussão sobre a relação entre Direito e Literatura ${ }^{2}$, para Ferreira Júnior (2016), há equivalentes entre a ficção processual, própria de uma lide, e a ficção literária - o que permite utilizar métodos típicos do estudo literário para analisar questões jurídicas. Indo além da metodologia mais difundida de buscar conceitos jurídicos em obras de ficção, a hipótese chave dessa pesquisa é que Antígona ocupa um lugar especial entre os campos de estudo. Conforme será desenvolvido, mais do que encontrar conceitos jurídicos na tragédia de Sófocles, a tensão entre Creonte e Antígona serve como alegoria para expressar o problema fundamental de qualquer Teoria do Direito ou processo judicial: a tensão entre pretensões diferentes de justiça, ou no vocabulário próprio da Filosofia do Direito Contemporânea, a tensão entre correção e segurança jurídica.

\section{A NARRATIVA DE SÓFOCLES E AS METÁFORAS DA DECISÃO DE ANTÍGONA}

Na Grécia Antiga inexistia separação entre política e religião. Tais instâncias, hoje separadas, compartilhavam o palco para as dramatizações, tanto para preservar e ensinar a tradição dos ritos religiosos, como para promover debates políticos. A vontade dos deuses e a esfera política confundiam-se.

Existem várias chaves para a interpretação da literatura grega, e uma das principais é a relação entre sociedade humana e a ordem natural guiada por deuses. Os gregos concebiam a ordem social assentada na ordem natural; Homero, Hesíodo, Heródoto, dentre outros nomes da literatura grega, tiveram como pano de fundo a mesma mitologia e a mesma sociedade grega, o mesmo imaginário e a mesma realidade. Mas cada escritor teve suas peculiaridades. Interpretaram a vontade dos deuses cada qual à sua forma e descreveram uma polis nas suas próprias perspectivas. Sófocles (496-406 a.C.) vivenciou a ascensão e o declínio de Atenas, por

\footnotetext{
2 Um importante estudo estabelecendo o estado da arte em termos metodológicos, além de realizar contribuições propondo instrumentos adicionais de análise, é feito por M. Paola Mittica, no texto "O que acontece além do oceano? Direito e Literatura na Europa" (2015).
} 
exemplo. Quando jovem ocupou cargos administrativos e lutou em conflitos militares, e já em idade avançada, vivencia a crise da democracia ateniense. Em sua vida conheceu de perto a vida política de sua cidade, elemento que aparece em suas obras (Rosenfield, 2002, p. 5-8).

Sófocles teve grande êxito em concursos literários, competindo sempre com grandes escritores que também deixaram seu nome na história, como Ésquilo e Eurípides. Antígona é uma das sete tragédias conservadas de Sófocles. Escreveu-a para um concurso, do qual foi vencedor, no ano 441 ou 440 A.C., o que lhe rendeu a eleição para estrategista militar, maior honra possível à um cidadão de Atenas daquela época.

De todas as tragédias gregas, Antígona foi a mais discutida e objeto de inúmeras reflexões. Kamerbeek, Hegel, Hölderlin, Nietzsche, Heidegger, Lacan, Derrida, Aristóteles, são alguns dos grandes nomes que estudaram a obra sofocliana ${ }^{3}$. Trata-se de um texto quase sem descrição, sendo composto essencialmente por diálogos entre os personagens, mas são nas linhas desses diálogos que a tragédia se desenvolve.

Antígona é a terceira parte da trilogia tebana e há um prelúdio na narrativa que precisa ser mencionado. Édipo havia sido amaldiçoado por ter matado seu pai, Lio, então Rei de Tebas, e por engano ter casado com sua mãe Jocasta. Teve quatro filhos, Etéocles, Polinice, Ismênia e Antígona. Com a morte de Édipo, iniciou-se uma guerra civil pela disputa da sucessão ao trono. Os dois irmãos, Etéocles e Polinice, comandavam forças antagônicas, e durante a batalha eles duelaram e acabaram se ferindo reciprocamente. Ambos morreram e Creonte, irmão de Édipo, assumiu o trono.

\footnotetext{
A presente pesquisa não estabelece o estado da arte a respeito da ampla produção teórica referente a tragédia de Sófocles. Trabalha em primeiro plano a leitura de Hegel que serve como contraponto a proposta de Ost. No entanto, outras interpretações paradigmáticas e que podem ser objeto de estudos próprios podem ser encontradas em: Retórica de Aristóteles, que oferece um importante contraponto entre Direito Natural e Direito Positivo; Nascimento da tragédia de Nietzsche, que analisa aspectos da obra sofocliana como um todo, em especial o impacto dela para a construção de ideários filosóficos; Espectros de Marx de Derrida, apresenta um viés sobre estética a partir de Antígona; em Ética da psicanálise Lacan incorpora Antígona em debates da psicanálise a partir de uma fundamentação filosófica, contraponto o modelo da ética kantiana ao código moral encontrado na personagem Antígona; Heidegger, na Introdução à metafísica, encontrou uma chave para compreender o ser grego expresso em algumas personagens da narrativa, especialmente no coro da peça; mas de todos os comentadores, Kamerbeek, na obra The plays of Sophocles estabeleceu de forma mais ampla as leituras já realizadas e em seu trabalho comentando as tragédias de Sófocles.
} 
O novo Rei de Tebas julgou que Etéocles estava coberto de razão durante o conflito e, por isso, culpou Polinice pelos transtornos causados. Creonte, então, conferiu todas as honras fúnebres possíveis ao sobrinho que, em seu entender, estava do lado certo, e resolveu punir o outro mesmo após a sua morte. Fez isso proibindo que seu corpo fosse sepultado, devendo ser deixado ao ar livre para ser devorado por animais selvagens.

Diante desses acontecimentos, a peça final da trilogia tebana começa com um diálogo entre as irmãs Antígona e Ismênia, que, em sigilo, discutem o édito de Creonte que proibiu enterrar o corpo de Polinice e de derramar lágrimas sobre ele. Porém, Antígona, que assume o arquétipo de heroína, pensa em enterrar o irmão e pede ajuda à sua irmã.

Ismênia reluta em ajudar, invocando argumentos de que as mulheres não poderiam se opor às forças dos homens que possuem a função de governantes. Restava a ela guardar o dever de obediência e, portanto, se vê em um conflito também, pois Antígona se sente negada pela irmã, mesmo não sendo essa a sua intenção. Ela reconhece a injustiça da situação, mas reafirma a falta de forças para se opor - o que não passa de uma desculpa para Antígona.

Esta, por sua vez, encontrava-se em um dilema inconciliável: as leis divinas obrigavam a enterrar seu irmão e a lei tebana proibia. Seriam atraídos maus augúrios e o descontentamento dos deuses se descumprisse as obrigações fúnebres, já que estariam sujeitos à pena capital quem prestasse homenagens fúnebres à Polinice. As leis divinas e as leis humanas, antes compatíveis, agora enfrentavam uma antinomia: cumprir uma lei seria trair a outra. Apesar do conflito, Antígona é resoluta, e sem temor da morte, realiza a vontade dos deuses.

A cena seguinte é protagonizada por Creonte, que como novo Rei enuncia qualidades desejadas de um governante, como tomar decisões tendo em vista o melhor interesse da cidade, sem se omitir de assuntos importantes. Ele mostra uma prontidão para o exercício de sua função e afirma também que não pode favorecer amigos em prejuízo da pátria. Por isso Polinice, mesmo sendo de sua família, teria que ser punido. Seu sobrinho tinha atentado contra Tebas, e a única forma de punir uma pessoa depois de seu óbito era proibir que sua morte fosse lamentada - que o corpo ficasse insepulto e fosse devorado por animais. 
Um coro na peça que, conforme a interpretação, representa a opinião popular ou o conselho de sábios, sugere à Creonte que o enterro é vontade dos deuses. Mas o Rei é irredutível em revogar a proibição de sepultar Polinice sob a pena capital. O conflito entre as duas personagens centrais, que representam forças opostas, era inevitável desde o início da tragédia. Antígona, então, enterra o irmão.

No desdobramento da cena, guardas levam a notícia para o Rei de que alguém enterrou Polinice. Imediatamente, os soldados são acuados pelo Rei por não terem cumprido o dever de vigiar o corpo, mas antes de represarias maiores, a força militar da cidade prepara uma armadilha: os guardas desenterram o corpo de Polinice e Antígona, ao tentar repetir seu ato de honrar seu irmão, é capturada e levada para diante de Creonte.

Creonte e Antígona ficam um de frente para o outro. O julgamento dela, que é o momento determinante para a leitura feita nessa pesquisa, inicia quando Creonte questiona se ela tinha conhecimento da lei e Antígona confessa que sim. É dada uma chance para ela declarar o desconhecimento da lei e ter uma penalidade diferente, mas a heroína é irredutível. Afirma que não foi Zeus que promulgou o decreto e que nenhum comando de um mortal tem poder para contrariar leis divinas que, apesar de não escritas, são irrevogáveis.

Creonte é acusado de tirania por Antígona, que afirma que apenas o próprio rei não percebia o que estava fazendo. Ela reivindica o apoio dos tebanos, que concordariam com ela se não fosse o temor que Creonte inspirava e o silêncio que mantinham para agradar ao rei. Para ela, era insustentável a posição de um mortal ir contra Hades, que exige que os dois irmãos recebam o mesmo rito. Ao Deus do submundo deveria ser dado aquilo que lhe pertence.

Por outro lado, a racionalidade de Creonte crê que seria injusto dar ao homem de bem o mesmo tratamento que o criminoso recebe. Tebas não poderia tratar seus amigos da mesma forma que trata seus traidores. Da mesma forma que acontece com Antígona, para Creonte só existe uma forma de olhar a situação. Assim, a condenação à morte, já prevista desde o início, é proferida.

No ato seguinte, Hémon, filho de Creonte e noivo de Antígona, decide falar com o Rei. Segue-se uma discussão sobre as posturas do rei, e a 
obediência de um povo ao seu governante. Uma das afirmações mais interessantes é quando ele diz que apenas em uma cidade de um homem só é que Creonte poderia governar sozinho, sem considerar a ordem dos deuses e os anseios do povo. Hémon afirma que o povo, ainda que de forma reservada, apoiava Antígona. Tais razões são levantadas para sustentar uma apelação do filho para que Creonte revogue o édito condenatório. Creonte cede, e a condenação de Antígona passa a ser a sua prisão em uma caverna.

Na sequência oráculos são ouvidos e, através da voz de Tirésias, alertam Creonte. A relação entre o mundo dos homens e o mundo dos deuses estava fragilizada, a ponto de que as preces dos mortais não eram mais ouvidas pelas divindades. É profetizado sofrimento à Creonte que, finalmente, depois de relutar, resolve libertar Antígona e enterrar Polinice.

A narrativa tem, enfim, o seu desfecho trágico. Quando foram libertar Antígona, descobriram que ela havia se enforcado. Pela frustração de não conseguir salvar sua noiva, Hémon também comete suicídio. Eurídice, mulher de Creonte, ao saber da morte do filho, também se mata ${ }^{4}$.

Esses são os pontos centrais da trama para o estudo aqui proposto. Pelo lirismo de Sófocles, na obra analisada, não existe mediação possível entre a lei imposta por Creonte e o sentimento de Antígona. Uma leitura inicial pode apontar Creonte como um tirano egoísta, mas ele não é um vilão. Seus argumentos possuem lógica e uma justificação. O Rei de Tebas pode ser acusado de não dialogar, ser obsessivo no cumprimento das leis e de falta de visão (Oliveira, 2013, p. 95-96). Mas ao adentrar em discussões da obra, notam-se traços equivalentes em Antígona.

Como característica própria da tragédia, busca-se mediar extremos. Antígona, no arquétipo de heroína, se vê obrigada a escolher entre dois bens, e independente da decisão, haverá suporte para críticas apontando algum erro. A escolha por uma obrigação leva a negligência de outro dever.

Há sempre duas ordens nas tragédias sofoclianas: ordem divina e ordem terrena. O conflito entre elas gera sofrimento e torna a vida insuportável, sendo preferível abraçar a morte. No fim das narrativas, as

Essa descrição resumida dos atos da peça foi elaborada a partir de diferentes traduções de Antígona (Sófocles, 1999; 2007; 2009). 
personagens são mais dignas do que eram no começo. A reconciliação entre as ordens, ou ao menos a sua tentativa, permite a dignidade (Carpeaux, 2011. p. 71-74).

Outra tensão importante, conforme Northrop Frye afirma ao analisar a estrutura dos mitos, decorre do modelo de sociedade presente em Antígona. Há uma tensão entre egos, cuja lealdade à um líder diminui o indivíduo. Em suas palavras:

\begin{abstract}
No sinistro mundo humano, um polo individual é o líder tirânico, inescrutável, implacável, melancólico e com uma vontade insaciável, que ordena a lealdade apenas se for egocêntrico o bastante para representar o ego coletivo de seus seguidores. O outro polo é representado pelo pharmakos, ou vítima sacrificada, que deve ser morta para fortalecer os outros (Frye, 2014, p. 278).
\end{abstract}

O conflito com a Lei do Estado é que torna Antígona símbolo de todas as resistências. Sem isso, ela seria apenas uma personagem sentimental. De toda forma, inúmeros conflitos podem ser expressos com a analogia com a última parte da trilogia tebana, conforme será discutido na próxima sessão.

\title{
3 A INEVITÁVEL TENSÃO ENTRE DIREITO E JUSTIÇA: DO DUALISMO À CONCILIAÇÃO
}

Há muitas interpretações possíveis da obra sofocliana. E isso não implica que algumas sejam verdadeiras e outras falsas, pois existem vários níveis e perspectivas possíveis para a leitura. Wayne Morrison, por exemplo, afirma que existe a tensão entre o público e privado; dever para com a família em conflito com deveres para com o Estado; amor e dever; homens e mulheres; tensão entre razão masculina e emotividade feminina; entre velhos e jovens; deuses e homens; sociedade e indivíduo; a importância dos mortos face aos vivos; razão teórica e razão prática; natureza a e cultura; dentre outros. Tais interpretações são consideradas como dualistas. Ainda assim, os conflitos mais recorrentes são os jurídicos (Morrison, 2006, p. 28).

No campo do Direito, uma das abordagens mais comumente tratadas é utilizar o dilema central de Antígona para expressar a oposição entre Direito natural e Direito positivo, como feito por Aristóteles, na medida em que há o conflito entre um dever natural que serve como imperativo para o enterro de Polinice e um dever legal da proibição de prestar as homenagens fúnebres devido ao decreto de Creonte. Outra leitura jurídica recorrente é 
interpretar a decisão de Antígona de enterrar seu irmão como um ato de desobediência civil, o que retoma as discussões em torno da concepção de justo para legitimar a decisão da protagonista.

Hegel promove uma interpretação mais rica. Ele consegue, com sucesso, dialogar com as mais importantes interpretações da obra de Sófocles feitas até sua época e será tomado como marco teórico para representar as leituras dualistas. Essa visão precisa ser construída para que, na sequência, haja um contraste com a interpretação feita por Ost. Hegel, além de pontuar conflitos existentes na obra - lei pública do estado e deveres familiares; dever em relação ao irmão e interesses da família; bem público e vontade dos deuses -, entende que os protagonistas se opõem e agem apenas a partir da parte do mundo que eles representam. Ele afirma "Antígona, Creonte etc. têm em vista fins individuais é certo, mas o substancial, que constitui o conteúdo patético dos seus atos, é legítimo e justificado e tem por isso um interesse universal" (Hegel, 1996, p. 622-623).

Para Hegel, a partir das tensões latentes da sociedade grega, cada personagem age em nome de um universal. ${ }^{5}$ Ismênia interpreta a questão a partir de um Direito natural, que subordinava as mulheres aos homens na sociedade grega antiga. Antígona foi movida por um Direito divino que determinava o dever de sepultar os parentes. Creonte era guiado por uma lei positiva, e assim por diante. Cada um era compelido a obedecer a uma lei e, com isso, era obrigado a desobedecer às demais. $\mathrm{O}$ filósofo alemão sustenta que Antígona é movida por uma injunção divina a realizar seus atos, uma injunção absoluta. Há uma exigência social de seguir as leis da comunidade, e também uma exigência supra-estatal de sepultar o corpo do irmão e dar a Hades o que lhe pertence. Creonte, por sua vez, está incumbido com a perspectiva da comunidade e, enquanto governante, recusa-se a conferir à um inimigo do Estado o devido funeral.

Hegel usa a tragédia de Antígona para expressar elementos de seu pensamento, identificando um movimento dialético sintetizador em direção

\footnotetext{
Os conceitos de "universal" e "essência" em Hegel não são objeto de análise nessa pesquisa. De todo modo, ele entende que a partir de Antígona é possível extrair uma metáfora para exemplificar a visão que ele possui acerca da filosofia. Mas isso não será discutido porque demandaria uma incursão em conceitos de sua filosofia, como a dialética, que desviariam demais do objeto proposto.
} 
ao todo. Assim, os conflitos entre instâncias são inevitáveis, como deveres para com a família e deveres em relação ao Estado. Reconhecer um dos lados significa negar o outro. Anteriormente, cada esfera fazia parte de uma polis, projetavam-se em embates em que cada parte reivindica a totalidade da substância ética. Creonte e Antígona, nesse sentido, são representantes das substâncias do Estado e da família, ou da ordem divina. Mas ambos arrogam-se representação da totalidade, razão pela qual cada um vai negar a validade da pretensão oposta (Salgado, 1996, p. 280).

Cada personagem age em nome de um telos. Creonte está justificado em fazer o édito proibitório ao buscar o bem da cidade. Antígona representava uma força sagrada que a movia para cumprir seus deveres para com os deuses e para com sua família. Hegel expressa esse entendimento na Fenomenologia do espírito:

Como só enxerga bem de um lado, e mal do outro, essa consciência que pertence à lei divina só vê do outro lado a violência do capricho humano, enquanto aquela que se atém à lei humana só vê do outro lado a obstinação e a desobediência do indivíduo que insiste em ser sua própria autoridade. Pois as prescrições do governo têm um significado universal e público, exposto à luz do dia; a vontade da outra lei, contudo, é examinada no escuro das regiões inferiores, e em sua existência externa manifestase como a vontade de um indivíduo isolado que, como se contradiz ao primeiro, constitui um ultraje brutal (Hegel, 1996, p. 253).

Tanto Antígona como Creonte realizam esforços sinceros para salvar Tebas, mas o choque entre os diferentes desígnios é inevitável, o que leva ao seu final trágico. Na interpretação de Hegel, Antígona, ao enterrar o irmão, realiza o cumprimento de uma ordem divina, do sangue, do amor fraternal. Creonte, por sua vez, representa a vontade do poder soberano, as máximas do Estado. Ambos não lutam por si, mas por ideais de outros. Duas forças legítimas e moralmente justificadas que se enfrentam é justamente o cerne da estrutura dramática grega (Hegel, 1993, p. 656).

Hölderlin, outro intérprete conceituado, vê uma questão de sucessão presente na trama, identificando elementos subtendidos no texto. Através dos diálogos, Antígona e Creonte fazem referência ao símbolo do poder, o palácio, como sua casa, uma vez que Antígona entende que sua linhagem teria precedência na sucessão. Para Hölderlin o problema sucessório é posto de forma implícita e torna mais complexa a leitura do conflito entre a 
questão religiosa e a política estatal. O significado do nome da heroína reforça essa indicação - Anti-gone significa: anti, no lugar da (ou contra), e gone, a progenitura (Rosenfield, 2002, p. 11).

O coro da obra chega a chamar Antígona de última raiz que trazia em si, em uma união com Hémon, como se fosse a possibilidade de dar continuidade a sua linhagem. Informações do contexto histórico da obra reforçam tal interpretação, conforme Rosenfield:

\begin{abstract}
Com efeito, o que Antígona representaria na Atenas histórica? Na época de Sófocles, existia uma instituição jurídica que assegurava um estatuto particular à filha de um chefe defunto. Este instrumento - o epiclerado garante à filha o direito de parir um sucessor para o seu pai morto, assegurando assim a continuidade da linhagem e do poder. Fosse Antígona uma princesa do século quinto, Creonte teria obrigação de casá-la, no regime do epiclerado, com seu mais próximo parente Hémon, filho de Creonte (Rosenfield, 2002, p. 11.-12).
\end{abstract}

Tais elementos justificam porque Creonte trata, de forma aparente, as filhas de Édipo com rispidez. Além da disputa religiosa, haveria toda uma questão dinástica em confronto (Rosenfield, 2002, p. 23).

As considerações apresentadas até aqui indicam o panorama das interpretações realizadas da tragédia. Cada comentador mencionado justificaria um estudo dedicado somente ao seu pensamento. Não se pretende, entretanto, expor a profundidade das reflexões sobre a tragédia dos teóricos citados, mas sim pontuar elementos que enriquecem a leitura de Antígona. Ainda assim, além das leituras dualistas que contrapõe elementos da tragédia, François Ost indica uma hipótese de uma dialética entre os opostos.

Antígona marca-se pela recusa da injustiça, fazendo com que seu grito rebelde ecoe por vinte e cinco séculos, partindo de Atenas. Ost considera-a imprudente por ter sido surda, por ignorar as objeções sensatas de Ismênia, por ignorar a lei positiva que violou, por não ouvir Creonte.

A novidade da interpretação de Ost é a tese de que as pretensões de Antígona e Creonte não devem ser pensadas em oposição, mas comunicadas de forma dialética. Creonte, na leitura dicotômica, realiza uma interpretação restrita das necessidades da polis. Ele acaba ignorando uma série de fatores necessários ao bem público em nome de um maniqueísmo entre amigos e inimigos. Trata-se de uma polis unilateral que não confere 
espaço ao outro. Justamente esses outros, como o filho e a esposa de Creonte, que os castiga ao final da narrativa. Antígona, por seu turno, realiza oposições de igual grandeza. Ost fala que, por vezes, ela possui o comportamento animalesco e, em outras, uma conduta compatível com a dos deuses.

Hegel assume o paradigma de leitura antagônica. Identifica dois mundos que serão destruídos no confronto. À Creonte é associada a lei humana e suas virtudes. Antígona, por sua vez, arroga-se da lei divina e é movida por atributos emocionais, fraternos, femininos. Desse embate, que por um momento se equilibram antes do desfecho da tragédia, levam ao desaparecimento das duas essências. Os personagens são apenas avatares da parte do mundo que eles representam (Ost, 2004, p. 200-201). Já Ost procura encontrar na tragédia de Sófocles uma metamensagem presente na narrativa. As proposições de Creonte e Antígona são simultaneamente justas e injustas, a desobediência civil também, o que levaria a uma terceira via.

Para Ost, uma camada importante da obra é o confronto entre Creonte e Antígona, que expressaria a tensão entre a razão de Estado e a objeção de consciência. É feito um questionamento sobre até qual limite os atos do Estado podem ser válidos. De certa forma, Ost retoma o conflito entre o Direito em vigor e Direito ideal, termos que ele prefere em vez de Direito positivo e Direito natural. A proibição de prestar homenagens afeta a esfera familiar, algo que não é claro se está no poder de legislar na CidadeEstado. Além disso, Creonte estaria tirando o que era de direito de Hades. Por outro lado, é próprio dos deuses do Olimpo proteger a pátria e castigar quem a ameace. A fronteira do justo e do injusto não é clara nessas questões (Ost, 2004, p. 189-190).

O justo positivo também não está de um único lado, pois pela posição de Hémon, do coro e de Tirésias trata-se uma questão contestada. Diante disso, deve-se sempre buscar deliberação a respeito disso, sendo um ato político negativo recusar o debate e decidir sozinho - o que se aplica tanto à Antígona como a Creonte.

Nesse contexto de sentimento de injustiça, a desobediência civil é trazida em primeiro plano. Trata-se de uma contestação interna ao próprio Estado, que é expressa por um ato público não violento, contrário a lei, mas 
com o intuito de promover uma mudança na lei ou em uma política de governo. Nesse sentido, Antígona fica ao lado de Henry Thoreau, Mahatma Gandhi e Martin Luther King. Este último que possui a célebre declaração "aquele que infringe uma lei porque sua consciência a considera injusta, e aceita voluntariamente uma pena de prisão a fim de despertar a consciência social contra essa injustiça, demonstra, em realidade um respeito superior pelo Direito" (apud Ost, 2004, p. 176). Antígona de Sófocles aparece, portanto, como modelo fantástico e inigualável de resistência ao poder. Ela faz uso de um remédio último quando não persiste alternativa de outra natureza. Os bloqueios e negativas entre os protagonistas leva-os a destruição recíproca, já que Creonte e Antígona recusam-se a ceder. Esse embate é consequência de diferentes concepções de justiça. Cada personagem tem suas razões para sustentar as respectivas crenças de que estão fazendo o que é certo.

São muitos os termos no texto original em grego que se referem à justiça que são usados pelos protagonistas para defender seus pontos de vista: Díke preocupa-se com a justiça dos mortos, invocado por Antígona na peça; Thémis é o nome mais antigo da deusa da justiça. Na poesia grega é dedicada a justiça familiar e divina; thesmos, palavra mencionada pelo coro, refere-se às velhas leis passadas de geração a geração, tendo sido estabelecidas pelos deuses no passado; o vocábulo nomos, podendo ser entendido lei, é empregada de modo equivalente, e várias vezes, pelos protagonistas. Nomos pode ser lida como "regra que presida a partilha de bens, fixando limites", mas progressivamente foi estabelecida na democracia de Atenas e passou a ter o sentido de lei trazendo um costume obrigatório; Antígona também invoca nomina, que são tradições, podendo ser interpretada também como leis de origem divina (Ost, 2004, p. 193-196).

Disso, Ost fala que não é possível associar a justiça reivindicada por Antígona à lei natural, não ao menos em uma interpretação restritiva. Para o jurista belga "a posição de Antígona é clara: o nomos político só tem validade dentro do quadro traçado pelas nomima divinas e imemoriais" (Ost, 2004, p. 196). O debate sobre justiça é complexo na tragédia, pois não há apenas uma forma de lei, Direito ou justiça que terá prevalência absoluta sobre as demais. 
O paradoxo fica em foco, várias justiças colidem. A exposição é conduzida para que, ora o leitor tome partido de uma parte, ora de outra. Por vezes defende o Direito em vigor e em outros momentos o Direito ideal evidencia-se. O essencial não é um Direito superar o outro, pois a tensão sempre vai existir. O Direito ideal sinaliza o limite intrínseco da lei positiva, mas ao mesmo tempo não torna a lei positiva desnecessária. Nas palavras de Ost:

Poderíamos dizer ainda que as relações do direito em vigor com o direito ideal são comparáveis às que mantêm entre si as fontes materiais e as fontes formais do direito: as segundas são visíveis e positivas, elas gozam da aura da oficialidade e ocupam todo o espaço jurídico aparente - os espíritos superficiais podem se contentar com isso; já as primeiras operam na sombra e fora dos canais oficiais - os espíritos avisados reconhecem nelas, sob a forma do processo de formação consuetudinário, de expressão de princípios, de reivindicação de direitos, a gênese verdadeira do jurídico. Para dizer ainda de outro modo, o direito em vigor é da ordem do instituído, o direito ideal é instituinte. E um não pode passar sem o outro: as forças instituintes são vertidas nas formas instituídas, num movimento de colaboração positivo (2004, p. 205-206).

A tragédia expõe esse movimento dialético de relação entre os níveis. É necessário e impossível ao mesmo tempo, tanto conformar-se com o direito em vigor, como buscar o Direito ideal. Entretanto, existe uma mediação possível. É teoricamente aceitável que uma regra seja justa em sua origem, mas se torne injusta em uma aplicação específica - é necessário ter atenção para isso. Posto isso, Ost afirma que no momento da decisão judicial será necessário a busca de uma correção tendo em vista o caso concreto (Ost, 2004, p. 206). Uma regra que foi justa ontem pode não ser mais adequada a realidade hoje, devendo ser realizada uma modificação ou revogação. Nessa parte da tragédia de Sófocles, Ost entende existir um processo de aprendizagem sobre como esse movimento do Direito ocorre.

A tragédia apresenta um conflito entre dois mundos que não dialogam, mas será possível haver na via judiciária uma alternativa? Ost entende que sim. Ele encontra espaço para discussão em alguns julgamentos que aparecem na obra. Como exemplos, Polinice foi condenado, Antígona teve um processo, assim como Ismênia e o guarda tiveram receio de serem acusados. Pode-se discutir o justo circunstancialmente nesses momentos e não em abstrato. O Direito, tanto 
hoje, como na Grécia Antiga, nunca se reduziu à lei, porque se manifesta também na forma de decisão (Ost, 2004, p. 208).

Em seu processo Antígona confessou sem rodeios a prática da conduta. Em seguida, Creonte examinou se ela sabia da proibição, que de forma orgulhosa ela declarou que sim. Ela sabe de seu destino, mas quer contestar diante da cidade a decisão que pesou sobre seu irmão insepulto. Hémon debate com o pai e consegue converter uma condenação capital que pesava sobre ela para um encarceramento em uma gruta. Creonte, para Ost, encarna em momentos diversos a função legislativa, judiciária e executiva, pois ele cria a lei, processa e confere indulto.

O Rei de Tebas tinha o poder para exercer essas funções mesmo contra a opinião de todos. Esse é um conflito recorrente nas obras de Sófocles. Além da peça aqui discutida, em Ajax, Electra e Filocteto é colocado o conflito entre um indivíduo e uma ordem política injusta. Há uma presença indireta do povo na peça, que se mostra enquanto opinião pública, que aparece por vezes no coro, ou na figura do guarda enquanto representante do povo. No entanto, na monarquia Tebana, a opinião do povo pode ser desconsiderada, já que Creonte é conhecedor das virtudes e dos poderes próprios aos monarcas. Além do mais, a partir de leituras sobre o Direito da Grécia Antiga, Ost afirma que ele suportava a possibilidade de proibir homenagens fúnebres aos inimigos. Isso aparece nas Leis de Platão, nos textos de Xenofonte, e também nas obras de Eurípedes, bem como em outras tragédias do próprio Sófocles. A privação que Creonte impôs não era estranha à época.

Antígona, Hemon, anciões, e por fim Tirésias, tentaram persuadir o Rei, mas seus esforços não tiveram resultados. Antígona, depois de frustradas tentativas de persuasão, apela para atos de resistência. Tomou sua decisão impelida por uma urgência de cessar o quanto antes a exposição do corpo de seu familiar insepulto. Há, porém, interpretações variadas sobre a resistência de Antígona, como um ato solitário de objeção de consciência, desobediência civil, ou até mesmo uma transgressão simbólica para tornar-se mártir. Independente do instituto jurídico que mais se amolde ao ato dela, sublinha-se a recusa diante de uma ordem injusta. A desobediência civil de Antígona assume várias características. Encontra-se na ação dela uma transgressão de uma regra de Direito em vigor, em que 
ocorre um apelo para a consciência pública, proveniente de uma minoria ou de um grupo atuante, que age de forma pacífica, transgredindo conscientemente e voluntariamente a lei impugnada, com o objetivo de modificar ou contestar a norma desobedecida fundada em um senso de justiça que apela a um Direito mais elevado (Ost, 2004, p. 223-228).

Em sua consciência, de forma imediata, podendo carecer de reflexão e racionalidade, forma-se o sentimento subjetivo de injustiça. Ainda que não seja possível definir o conceito de justiça para poder saber o que é justo, seguindo os passos de Platão, é possível identificar com clareza situações permeadas de injustiça. Não é possível olhar para o sol diretamente e não se cegar, mas é fácil ver deturpações nas sombras formadas. A partir disso, Ost propõe que a formulação de Antígona é sobre injustiça, não sobre escolas e conceitos teóricos que só surgiram posteriormente à tragédia. Trata-se de uma convicção que basta a si mesma e que não tem necessidade de argumentar ou convencer.

Todas essas tensões chocam-se no julgamento de Antígona. Creonte, ao decidir sobre o destino dela deliberou sobre as diversas justiças presentes na obra. A conciliação total sempre foi impossível, mas é no momento jurisdicional que o melhor equilíbrio existente entre os mundos pode ser buscado. É aí que o diálogo acontece e uma decisão não injusta poderia ser dada. Com a falta disso, seguiu-se o desfecho trágico.

Ao demonstrar o conflito entre diferentes pretensões de justiça e colocar como ponto de convergência o julgamento, Antígona consagra-se como marco inicial da Filosofia do Direito. É ambição desta área fornecer uma diretriz racional para a vida prática. A tarefa do filósofo do Direito não é propriamente a ideia metafísica, mas deve contribuir através de reflexões para a melhor solução de casos na vida prática onde pretensões inconciliáveis de justiça se encontram (Morrison, 2006, p. 31).

\section{CORREÇÃO E SEGURANÇA JURÍDICA: A QUESTÃo CENTRAL DAS DICUSSÕES JURÍDICAS}

A relação entre segurança jurídica e correção é um problema perpétuo da teoria e da prática do Direito. A tensão entre esses dois elementos fundamentais é necessária para aprofundar a discussão sobre a natureza, o conceito e a finalidade do Direito, dentre outras perguntas jusfilosóficas 
centrais que carecem de resposta definitiva há mais de 2.500 anos e ocupam a reflexão dos grandes juristas (Alexy, 2015, p. 1).

Jürgen Habermas analisa a tensão entre a segurança jurídica e a correção normativa, tanto no momento da criação legislativa das normas, quanto em sua aplicação. O dilema de Antígona, tanto no modelo de Hegel, como no de Ost, pode ser relacionado com essa problemática. A tragédia de Sófocles expõe a questão central do Direito, e seja em uma perspectiva filosófica ou a partir da Teoria do Direito, a questão central, desde a Antiguidade até hoje, é expressa como o problema entre segurança jurídica e correção. De um lado é preciso respeitar o Direito posto, do outro lado exige-se justiça de um Direito ideal.

Robert Alexy sustenta que segurança jurídica e correção são princípios que colidem e nessa ponderação é expressa uma natureza dual do Direito. Assim como pensa Habermas, haverá uma tensão entre a dimensão da facticidade, uma dimensão real que define autoridade e eficácia, e de outro lado, a busca pela validade do Direito, uma dimensão ideal, que se preocupa com o conteúdo do Direito.

A segurança jurídica estabiliza as expectativas de comportamento através de da ordem jurídica, propiciando consistência e uma coerência com o passado jurídico de dada sociedade, considerando o respectivo contexto social. Por isso esse primeiro princípio exige que o ordenamento jurídico determine, tanto quanto possível, o conjunto de normas que devem ser observadas pelos destinatários. Por conta dessa característica central, há uma conexão entre segurança jurídica e positivação do Direito.

Por outro lado, o princípio de correção exige que o conteúdo do Direito seja correto. De forma mais simples, é necessário que o conteúdo seja justo, o que passa por questões morais. Alexy inclui a necessidade de uma correção em um nível conceitual do Direito, o que leva, de forma inevitável, ao uso de um modelo não positivista de Direito. Se for reconhecida a importância da justiça para a discussão jurídica, o que é uma premissa aceita pelos teóricos pós-positivistas que enfrentam casos difíceis, é necessária uma natureza dual do Direito (Alexy, 2015, p. 2). Ao mesmo tempo em que o Direito exerce sua imperatividade, sua atuação deve ser legitima e aceita por seus concernidos. Deve haver razões práticas para que o sujeito cumpra seus deveres que decorrem de lei, como não cometer atos 
ilícitos e pagar seus tributos. Correção pressupõe justificabilidade do que é comandado, proibido ou facultado. Tais deveres precisam de uma justificação racional, que no pensamento de Alexy assume a forma de uma argumentação racional pautada em procedimentos discursivos. No entanto, há diversos outros modelos racionais para discutir a correção do Direito.

A segurança jurídica, garantindo que as expectativas em termos de conduta sejam asseguradas, pode ser conquistada através da positividade e eficácia dos comandos. Do outro lado, a correção, para ser assegurada, precisa, além da justiça, da segurança jurídica. A correção refere-se tanto a ordem real quanto a ideal, pois a pretensão de justiça, para ser efetiva, não pode limitar-se a um plano ideal. Tais princípios frequentemente colidem, e nenhum terá prevalência sobre o outro em todos os casos, pois essa tensão é parte da natureza do Direito e aparece em todos os sistemas jurídicos (Alexy, 2015, p. 6-7). Isso leva a outros problemas que devem ser examinados, em especial o da argumentação jurídica.

Habermas apresenta o problema, também expressado pelas alegorias presentes em Antígona, da seguinte forma:

\begin{abstract}
O problema da racionalidade da jurisprudência consiste, pois, em saber como a aplicação de um direito contingente pode ser feita internamente e fundamentada racionalmente no plano externo, a fim de garantir simultaneamente a segurança jurídica e a correção (Habermas, 1997, p. 247).
\end{abstract}

Nota-se também que a tensão problematizada surge no momento da criação e da aplicação do Direito. Em ambos os momentos a consistência e a aceitabilidade devem ser observados. Ao longo da história do Direito, diferentes modelos teóricos buscaram lidar com a necessidade de correção, enquanto pretensão de decisão justa, e com a segurança jurídica, garantindo a expectativa de comportamento a partir da norma.

Alexy enriquece a discussão ao identificar um elemento paradoxal nos Direitos Fundamentais, e de forma mais ampla no sistema jurídico. Há uma tensão entre a democracia e a jurisdição constitucional que implica no fato de que os Direitos Fundamentais são, ao mesmo tempo, democráticos e não-democráticos, ou legítimos e não-legítimos - fazendo a adaptação para o dilema de Antígona. Os Direitos Fundamentais são democráticos no momento de sua criação por um órgão legislativo que possui legitimidade para representação popular. Em um momento inicial, o legislador pode 
consignar em um catálogo harmônico de diversos direitos e garantias fundamentais, como liberdade, propriedade, vida, igualdade, dentre outros direitos citados comumente nas constituições. É conferido condições para que as pessoas realizem seus planos de vida, assegurando a continuidade das instituições democráticas. Por outro lado, são não-democráticos porque no momento jurisdicional nem sempre a decisão corresponderá à vontade da maioria, ou aos melhores argumentos. Os direitos, antes harmônicos, agora colidem, e a prevalência de um implica no afastamento de outro. Ademais, contemporaneamente um tribunal constitucional fica acima do processo democrático. Os direitos antes criados de forma democrática, em um caso difícil concreto, podem ser excluídos por um voto de diferença e a população se vê excluída de qualquer procedimento discursivo (Alexy, 2008, p. 49-54).

O grande desafio dos juristas é lidar com casos especiais, como quando ocorre o momento não-democrático dos direitos, quando a justiça de um implica na injustiça de outro, quando é impossível satisfazer todos os princípios ao mesmo tempo - características presentes em Antígona. Nessas situações de conciliação impossível, deve-se buscar a melhor solução utilizando-se dos dois princípios que devem ser harmonizados. Cada teoria jurídica equilibra de forma diferente esse problema. As principais diferenças entre esses modelos jurídicos decorrem de como eles fundamentam e equilibram as pretensões de correção e segurança jurídica.

Até o advento do positivismo jurídico, as teorias fundamentadas em alguma concepção de Direito Natural dominavam o espaço. Cada uma tendo um conteúdo em termos de correção diferente, mas tinham como constante que o Direito Positivo deveria observar o Direito Natural. Após o abandono de uma construção pautada na metafísica, Habermas identifica no panorama acadêmico contemporâneo, cinco teorias jurídicas que trataram diretamente do problema da correção e da segurança jurídica. Cada uma ofereceu uma resposta diferente para a questão que pode ser utilizada para analisar a tragédia Antígona.

A primeira é a Hermenêutica jurídica, que segue um modelo processual de interpretação. Possui como marco teórico Hans Georg Gadamer, cujas reflexões foram depois internalizadas em discursos jurídicos por pensadores como Konrad Hesse e Friedrich Muller. Nessa 
vertente, a decisão judicial é precedida por uma pré-interpretação, ou précompreensão, que verifica a relação entre norma e realidade. Na busca de uma solução racional da questão jurídica, respeitando o contexto histórico e o ethos dominante, a tradição é utilizada para legitimar a decisão. Esse modelo privilegia a correção e pensa a segurança jurídica de forma secundária. Por fim, essa teoria, apesar de influenciar uma geração de juristas e o pensamento de Gadamer ter sua devida atualidade, encontra dificuldades de achar correção em sociedades plurais. Aproximando esse modelo de Antígona, a protagonista teria uma base nas tradições que legitimariam sua ação. A proibição de Creonte seria apenas mais um elemento, dentre outros, que seriam considerados na elaboração da decisão mais coerente com os valores dominantes que por fim prevaleceriam, como de fato prevalecem ao final da tragédia.

A segunda teoria chama-se Realismo Jurídico, pois considera o processo de decisão sob uma perspectiva realista no que concerne às relações de poder que regem o processo de aplicação do Direito. O próprio julgador está inserido em um contexto histórico e sofre pressões diferentes de poder que influenciam seu convencimento. Para o Realismo Jurídico, não é possível distinguir elementos jurídicos dos políticos no processo de decisão judicial. Os valores nesse modelo também acabam sendo dominantes, mas a correção é encontrada em relação a quem possui maior influência nas decisões judiciais. Ao utilizar essa óptica para analisar a obra de Sófocles, nota-se que Creonte possui a autoridade determinante no processo de tomada de decisão. Os deuses podem ter influência na tradição e conversar com os Oráculos, mas dentro do palácio, na centralidade do poder, é a voz do Rei que domina. Assim, pela correção de quem detém o poder, Creonte estaria legitimado a mandar e desmandar, como assim o fez.

A terceira é o Positivismo jurídico, com destaque a Hans Kelsen, que analisou o Direito de forma metodologicamente pura. Ele afasta influências morais e políticas de sua descrição do Direito - superando assim a Hermenêutica Jurídica e o Realismo Jurídico. Sem afetações de qualquer ordem, e sem dever tributo em termos de correção a influências externas, o processo de decisão é examinado de forma estritamente formal, com primazia absoluta da segurança jurídica. Justiça é um atributo desejável para os participantes de uma comunidade, mas não necessário para 
caracterizar o Direito. E, ainda, na eventualidade de um caso difícil em que a ordem jurídica posta seja insuficiente, entendem os positivistas que o magistrado seria portador de ampla discricionariedade (Hart, 2007, p. 155). Na tragédia discutida, é inquestionável que o Rei de Tebas era a autoridade competente para criar e aplicar o Direito, sendo assim, incabível, a partir do Positivismo Jurídico, reacender qualquer discussão sobre justiça. Tal perspectiva axiológica é estranha à ciência do Direito.

Essas três primeiras teorias marcam o debate no contexto do Positivismo Jurídico. Mas com o pós-positivismo jurídico, na busca de uma reaproximação ente Direito e valores de forma não metafísica, Habermas pontua os dois últimos modelos teóricos: o Direito como Integridade de Ronald Dworkin; e a Teoria Procedimental do Direito, tendo como marco teórico o próprio Habermas e Alexy.

Dworkin apresenta críticas aos modelos teóricos anteriores e pensa uma Teoria do Direito em conjunto com uma Teoria da Justiça. Confere validade ao conteúdo das normas jurídicas a partir de uma justificativa racional desenvolvida em uma Teoria da Justiça, que por seu turno, recorre a uma organização social ontologicamente anterior a justiça, na qual podem ser encontrados valores comuns. Dworkin afirma que "cada um aceita a integridade política como um ideal político distinto, e trata a aceitação geral desse ideal" (Dworkin, 1999, p. 255). Quando as normas são positivadas, os conteúdos morais dos princípios originados na comunidade são assimilados. A integridade da comunidade norteia a atividade legislativa e jurisdicional.

Nesse modelo, que não é objetivo esgotar neste momento, Dworkin busca assegurar simultaneamente a correção e a segurança jurídica, especialmente quando o julgador está diante de um caso difícil. A justiça da decisão se daria na medida em que possui uma justificativa externa ao Direito, o que foi dado quando princípios fundamentais foram incorporadores na criação do Direito. Por outro lado, há expectativas de comportamento que devem ser asseguradas, e isso se faz na medida em que os valores e suas diretrizes são perseguidos pela decisão jurídica. Se a forma jurídica for assegurada, bem como o norte axiológico, estaria a segurança jurídica simultaneamente assegurada. Basicamente, ele modifica a forma de 
se garantir a segurança jurídica. Tal princípio seria atingido na medida em que existisse correção, pois essa é a expectativa principal dos sujeitos.

A aplicação ideal entre segurança jurídica e correção seria uma tarefa hercúlea. Por isso Dworkin realiza o experimento mental do juiz Hércules, que seria onisciente e decidiria considerando todas as fontes do Direito e todos os princípios e objetivos políticos externos ao Direito. Somente um juiz com tal capacidade, seria capaz de realizar a melhor interpretação possível e decidir da melhor forma um caso difícil. Apesar de ser um juiz ideal, serve como referência contrafática para julgar a realidade. Tanto mais correção e segurança jurídica estarão presentes em uma decisão, quanto mais princípios internos e externos do Direito forem considerados (Dworkin, 1999. p. 305). Intérpretes podem buscar a melhor interpretação existente se aproximando o máximo possível do ideal hercúleo.

Dworkin oferece um modelo que pode superar as teorias anteriores, mas a tensão básica entre correção e segurança jurídica ainda se apoia em elementos ideais, permanecendo em aberto para intérpretes limitados à melhor forma de decidir, de forma justa e conforme o Direito. Hércules é o único juiz capaz de oferecer uma solução correta, e o faz de forma monológica. Inicialmente, os cidadãos são importantes para a aceitabilidade dos princípios de justiça, mas na decisão judicial, o juiz ideal basta a si próprio. Dworkin parece não lidar adequadamente com o pluralismo a partir do juiz ideal.

Cada magistrado se colocaria, tanto quanto possível, na posição de realizar o trabalho hercúleo, permanecendo assim a objeção central. Tal modelo teórico é o que mais se aproxima das considerações feitas por Ost sobre a tragédia de Antígona. Um juiz ideal, a partir da concepção de Direito como integridade, consideraria os princípios de justiça existentes (buscando a correção externa) e equilibraria com o Direito em vigor (com o aspecto interno que regulamentava as condutas). Não é claro o que Hércules decidiria, pois há vários elementos a serem considerados, mas sem dúvida seria a solução mais fundamentada de todos os modelos.

Por fim, Habermas propõe um modelo discursivo para compreender o Direito, conferindo um espaço central para a intersubjetividade. Em sua teoria, que não é objeto de análise direto desta pesquisa, oferece também uma reformulação da forma de se conseguir correção e segurança jurídica. 
O modelo procedimental é pautado em argumentos que permitem a apresentação de razões orientadas ao consenso. Se condições discursivas forem observadas no momento de debates racionais, possibilitando que todos tenham a liberdade de fala, em igualdade e sem coerção, haverá segurança jurídica. O consenso para Habermas, qualquer que seja seu conteúdo, desde que observadas as condições de fala e o consentimento de todos os atingidos, terá correção. Vale observar que o processo de discurso se mantém aberto para que novos argumentos possam ser postos. Tanto mais legítimo o consenso, quanto mais um auditório universal de Perelman seja atingido 6 . Sempre se busca a prevalência do melhor argumento.

A correção, portanto, está vinculada à legitimidade da teoria procedimental que busca garantir a racionalidade do processo democrático que institui a legislação. Trata-se de uma teoria complexa, mas com o ponto de chegada simples. Se uma sociedade democrática decidiu que algo seria justo, seguindo os procedimentos discursivos, tal decisão é dotada de correção. Mediar o processo decisório e a criação de normas jurídicas com a questão da correção normativa é pertinente e enriquecedor para solucionar casos difíceis, próprios da sociedade complexa. A teoria do discursivo revela perspectivas consistentes, que através delas pode-se elevar o grau de legitimidade da fundamentação e da aplicação do Direito nas sociedades plurais. A partir dessa teoria, é impossível antecipar qual seria a desfecho do julgamento de Antígona.

Mesmo depois de séculos da tragédia de Sófocles, ainda não se sabe qual seria a solução mais correta para o caso e possivelmente nunca se saberá. Cada modelo jurídico já desenvolvido proporciona uma resposta diferente ao dilema de Antígona. As Teorias do Direito e as Teorias da Justiça que debatem sobre qual é a melhor forma de proporcionar simultaneamente Direito e Justiça, segurança jurídica e correção, enfrentam uma tarefa perpétua. A tragédia de Antígona serve para ilustrar o dilema fundamental, objeto de reflexão, mas consiste em uma tarefa inalcançável.

Ao citar auditório universal faz-se uma alusão à reflexão de Perelman: "É óbvio que o valor dessa unanimidade depende do número e da qualidade dos que a manifestam, sendo o limite atingido, nessa área, pelo acordo do auditório universal. Trata-se evidentemente, nesse caso, não de um fato experimentalmente provado, mas de uma universalidade e de uma unanimidade que o orador imagina, do acordo de um auditório que deveria ser universal [...]" (2005, p. 35). 
Mesmo que a ficção de Sófocles seja resolvida, ou que uma solução pareça ser mais persuasiva do que as outras, eventualmente prevalecendo em um auditório universal de Perelman, ainda assim poderão surgir casos difíceis que possuirão a mesma estrutura fundamental que Antígona: de um lado elementos do Direito Positivo, de outro lado demandas por justiça. Casos polêmicos sempre existirão potencialmente, e com isso existirão também dois momentos, um em que as normas jurídicas e os valores sociais coexistem, e outro em que um valor ou uma norma deve prevalecer sobre os demais. Essa é a interminável narrativa do Direito e não é lícito aos juristas evitarem os casos difíceis que o futuro lhes reserva.

\section{CONCLUSÃo}

A partir da apresentação da tragédia grega Antígona, foi estabelecida como interpretação dominante a leitura dualista. Entre os intérpretes, conferiu-se destaque a Hegel, que em seus comentários à peça de Sófocles enaltece a existência de extremos irreconciliáveis personificados por Creonte e Antígona.

A partir desta perspectiva, a pesquisa estabeleceu uma conexão inexplorada entre Filosofia do Direito, Hermenêutica Jurídica e Literatura. É próprio dos modelos teóricos existentes na Filosofia do Direito discutir teorias da justiça e como elas se relacionam com a ordem jurídica positivada. Ao longo do texto foi possível tratar do protagonismo desse problema em alguns dos principais paradigmas do Direito. Cada teoria equilibra as pretensões de correção e segurança jurídica forma distinta, o que repercute na forma como tais teorias enfrentam problemas sobre interpretação jurídica. No processo de decisão, a cada julgamento, pode-se conferir mais importância a justiça positiva expressa na lei humana, ou em concepções axiológicas de justiça próprias de uma lei ideal.

É próprio de grandes obras suportar múltiplas camadas de interpretação. Mas em Antígona, e isso enaltece importância da tragédia para o Direito, todo problema jurídico encontra repercussão nas metáforas da obra. Cada personagem encarna uma pretensão diferente de justiça, assim como acontece em toda e qualquer lide.

No problema jurídico da argumentação há a mesma tensão presente na tragédia de Sófocles. Em Antígona, havia duas ordens legais válidas e 
coexistentes: deviam-se honrar os deuses e cumprir os comandos terrenos do Rei. De certa forma, esse momento harmônico corresponde à etapa democrática descrita por Alexy: normas que não colidem. Entretanto, basta existir um conflito na realidade concreta para que o momento jurisdicional deva entrar em ação e decidir de forma não-democrática. Na tragédia sofocliana, a pretensão de Antígona ou a de Creonte deveria ceder para que a outra se realizasse. Esse é o elemento não-democrático pontuado pelo jurista alemão. Não existe conciliação possível e o conflito deve ser solucionado. A justiça de um será sempre a injustiça de outro. Essa é a tragédia cotidiana do jurista.

Entretanto, para além do dualismo Hegeliano da leitura de Antígona, vimos que Ost sustenta uma conciliação possível entre os extremos aparentemente incomensuráveis. Essa deve ser a atuação excelente de um magistrado ao tentar conciliar as normas que foram criadas de forma harmônica, mas que colidem em um caso concreto. A solução ideal passa pela tensão entre segurança jurídica e correção normativa. Entre o que o Direito manda e o que a justiça exige. Ou como em Antígona, entre a autoridade de Creonte e a vontade dos deuses. Diferentes paradigmas da Filosofia do Direito encontraram soluções diferentes para esse dilema.

A conciliação através da melhor aplicação do Direito não aconteceu no julgamento de Antígona. Por analogia, prevaleceu a resposta do positivismo jurídico que reconhecia como único direito válido aquele emanado e aplicado por autoridades competentes. Por outro lado, se o julgador entendesse que Antígona era possuidora da razão absoluta, a segurança jurídica estaria comprometida.

Esta pesquisa identifica um maior potencial na contribuição de Ost. Antígona, mais do que permitir trabalhar certo conceito jurídico, permite trabalhar o problema jurídico essencial. Claro que também tem conceitos que podem ser trabalhados, como a tensão entre Direito Natural e Direito Positivo. Mas mais do que isso, ela permite trabalhar qualquer questão jurídica. É próprio das alegorias poderem ser interpretadas de múltiplas formas. E por mais numerosas que tais interpretações sejam, sempre há espaço para novas leituras surgirem. Essa é a grandiosidade da obra de Sófocles. 
Todo jurista ao interpretar uma norma tem que repetir as decisões de Antígona. Ela teve dois dilemas principais: um interno, que julgou como injusto o comando da autoridade competente; e outro externo, que foi a violação da regra pelo ato de desobediência. $O$ intérprete, seja magistrado do Tribunal Constitucional ou um leigo, deve passar pelo questionamento se determinado comando é justo ou injusto e o que fazer a partir disso. Independente da decisão, é próprio do ofício de jurista a racionalização e a argumentação para sustentar a melhor compreensão do Direito.

\section{REFERÊNCIAS}

ALEXY, Robert. Constitucionalismo discursivo. 2. ed. Trad. de Luís Afonso Heck. Porto Alegre: Livraria do Advogado, 2008.

ALEXY, Robert. Legal Certainty and Correctness. Ratio Juris, v. 28, n. 4, p. 441-451, 2015.

CARPEAUX, Otto Maria. História da literatura ocidental. Brasília, Senado Federal, 2011. v. 1.

DWORKIN, Ronald. O império do direito. Trad. de Jefferson Luiz Camargo. São Paulo: Martins Fontes, 1999.

FERREIRA JÚNIOR, Ednaldo Silva. Semelhanças entre a ficção jurídica e a ficção literária: os processos judiciais enquanto narrativas ancoradas na realidade. Anamorphosis - Revista Internacional de Direito e Literatura, v. 2, n. 2, p. 349-370, 2016. doi: 10.21119/anamps.22.349-370.

FRYE, Northrop. Anatomia da crítica: quatro ensaios. Trad. de Marcus de Martini. São Paulo: É realizações, 2014.

HABERMAS, Jürgen. Direito e democracia: entre facticidade e validade. Trad. de Flávio Beno Seibeneichler. Rio de Janeiro: Tempo Brasileiro,1997. v. 1.

HART, H. L. A. O conceito de direito. Trad. de A. Ribeiro Mendes. 5. ed. Lisboa: Fundação Calouste Gulbenkian, 2007.

HEGEL, Georg Wilhelm Friedrich. Curso de estética: o belo na arte. Trad. de Orlando Vitorino e Álvaro Ribeiro. São Paulo: Martins Fontes, 1996.

MITTICA, Paola M. O que acontece além do oceano? Direito e Literatura na Europa. Anamorphosis - Revista Internacional de Direito e Literatura, v. 1, n. 1, p. 3-36, 2015. doi: 10.21119/anamps.11.3-36.

MORRISON, Wayne. Filosofia do direito: dos gregos ao pós-modernismo. Trad. de Jefferson Luiz Camargo. Revisão técnica de Gildo Sá Leitão Rios. São Paulo: Martins Fontes, 2006.

OST, François. Contar a lei: as fontes do imaginário jurídico. Trad. de Paulo Neves. São Leopoldo: Editora Unisinos, 2004. 
OLIVEIRA, Janio Davila de. O discurso de Creonte na "Antígona" de Sófocles. Fragmentum, Santa Maria, v. 1, n. 38, p. 85-96, 2013. doi: 10.5902/13769.

PERELMAN, Chaïm; OLBRECHTS-TYTECA, Lucie. Tratado da argumentação: a nova retórica. Trad. de Maria Ermantina de Almeida Prado Galvão. 2. ed. São Paulo: Martins Fontes, 2005.

ROSENFIELD, Kathrin H. Sófocles \& Antígona. Rio de Janeiro: Zahar, 2002.

SALGADO, Joaquim Carlos. A idéia de justiça em Hegel. São Paulo: Loyola, 1996.

SÓFOCLES. Antígona. Trad. de Donaldo Schuler. Porto Alegre: L\&PM, 1999.

SÓFOCLES. Três tragédias gregas. Trad. de Guilherme de Almeida e Trajano Vieira. São Paulo: Perspectiva, 2007.

SÓFOCLES. A trilogia tebana. Trad. de Mário da Gama Kury. Rio de Janeiro: Zahar, 2009.

Aceito: 14/06/18 